\title{
Liver Steatosis Following Supplementation with Fat in Dairy Cow Diets
}

\author{
V. LUBOJACKÁ ${ }^{1}$, A. PECHOVÁ ${ }^{1}$, R. DVOŘ́́K ${ }^{1}$, P. DRASTICH ${ }^{1}$, \\ V. KUMMER ${ }^{2}$, J. POUL $^{3}$ \\ ${ }^{1}$ Clinic of Diseases of Ruminants, University of Veterinary \\ and Pharmaceutical Sciences Brno, Czech Republic \\ 2 Veterinary Research Institute Brno, Czech Republic \\ ${ }^{3}$ ZOD Žichílek, Czech Republic \\ Received February 16, 2004 \\ Accepted June 6, 2005
}

\begin{abstract}
Lubojacká V., A. Pechová, R. Dvořák, P. Drastich, V. Kummer, J. Poul: Liver Steatosis Following Supplementation with Fat in Dairy Cow Diets. Acta Vet Brno 2005, 74: 217 224.

The aim of the present investigation was to determine the influence of increased intake of fats (calciferous salts of fatty acids) in the early lactation period on the development of liver steatosis. Twenty dairy cows in the study were divided into an experimental group $(\mathrm{E} ; \mathrm{n}=10)$ and a control group $(C ; n=10)$. Balanced diets of energy content, crude protein and minerals (except calcium) were fed to the two groups of dairy cows. The differences were in the fat content $(3.7 \%$ and $6.99 \%$ dietary dry matter in the control and experimental groups, respectively), fibre (14.4\% and $15.6 \%$ dietary dry matter in the control and experimental groups, respectively) and calcium $(0.83 \%$ and $1.3 \%$ dietary dry matter in the control and experimental groups, respectively). The source of fats in the diet fed to the experimental group was treated rape cake (calciferous salts of fatty acids). The two diets were introduced on the day of calving. Blood samples were collected in weeks 2 and 4 post partum, and liver biopsies were performed in week 4 post partum.

The histological examination of liver samples showed a significantly higher lipid infiltration $(69.03 \pm 8.42$ vs. $23.83 \pm 5.16 \% ; p<0.01)$ and significantly lower liver glycogen concentrations $(25.74 \pm 2.74 \%$ vs. $53.15 \pm 1.74 \% ; p<0.01)$. Two weeks post partum, the experimental group had significantly higher blood serum concentrations of betahydroxybutyrate - BHB (1.04 \pm 0.58 vs. $\left.0.54 \pm 0.18 \mathrm{mmol}^{-1} \mathrm{l}^{-1} ; p<0.05\right)$, non-esterified fatty acids - NEFA $(0.96 \pm 0.57$ vs. $0.39 \pm 0.24$ $\left.\mathrm{mmol} \cdot \mathrm{l}^{-1} ; p<0.05\right)$, total cholesterol $\left(3.54 \pm 1.29 \mathrm{vs} .2 .51 \pm 0.44 \mathrm{mmol} \cdot \mathrm{l}^{-1} ; p<0.05\right)$, total bilirubin $\left(8.61 \pm 3.73\right.$ vs. $\left.5.29 \pm 1.07 \mu \mathrm{mol} \cdot 1^{-1} ; p<0.05\right)$, lactate dehydrogenase $-\mathrm{LDH}(49.79 \pm 12.43 \mathrm{vs}$. $\left.37.20 \pm 5.48 \mu \mathrm{kat} \cdot \mathrm{l}^{-1} ; p<0.05\right)$, significantly lower concentrations of total protein $(78.77 \pm 5.01$ vs. $\left.88.72 \pm 7.05 \mathrm{~g} \cdot \mathrm{l}^{-1} ; p<0.01\right)$ and urea $\left(4.09 \pm 0.92\right.$ vs. $\left.4.99 \pm 0.61 \mathrm{mmol} \cdot \mathrm{l}^{-1} ; p<0.05\right)$. In week 4 post partum, the experimental group had significantly higher concentrations of NEFA $\left(0.62 \pm 0.48\right.$ vs. $\left.0.25 \pm 0.1 \mathrm{mmol} \cdot 1^{-1} ; p<0.05\right)$, total cholesterol $\left(4.70 \pm 0.77 \mathrm{vs} .3 .03 \pm 0.49 \mathrm{mmol} \cdot \mathrm{l}^{-1}\right.$; $p<0.01), \mathrm{LDH}\left(45.97 \pm 10.70 \mathrm{vs} .36 .14 \pm 3.97 \mu \mathrm{kat} \cdot \mathrm{l}^{-1} ; p<0.05\right)$ and significantly lower concentration of urea (4.43 \pm 1.01 vs. $\left.5.88 \pm 1.08 \mathrm{mmol} \cdot \mathrm{l}^{-1} ; p<0.01\right)$.
\end{abstract}

Our investigations suggest that increased intake of fats $(6.99 \%$ dietary dry matter $)$ in the early lactation period has a substantial effect on the development of liver steatosis.

Fatty liver, liver biopsy, blood, glycogen, triacylglycerol

In recent years, the production efficiency of dairy cows has constantly been increasing, which has led to higher demands on the supply of their nutrients. The most difficult problems have been encountered in the early lactation period when dairy cows have a negative energy balance. The main problem of that period is the limited intake capacity for dry matter, as a consequence of which dairy cows are unable to cover their energy needs from feeds. In an effort to obtain the energy necessary for milk production, the cows use up their bodily reserves, predominantly fats. An energy deficit at the beginning of lactation negatively impacts health, efficiency and reproduction performance of dairy cows. 
Liver steatosis has been linked to the post partum disruption of energy metabolism in dairy cows, particularly the ones with very good body condition indices (Van den Top et al. 1995; Rukkwamsuk et al. 1999). Feed intake negatively correlates with body condition parameters. Fat cows have lower feed intake because they mobilize their bodily fat reserves more extensively. There is an increase in blood plasma concentrations of nonesterified fatty acids, which are bound to albumin and transported to the liver. In the liver, they may be oxidized to $\mathrm{CO}_{2}$ or ketone bodies, or they are re-esterified to triacylglycerols. Triacylglycerols are then combined with phospholipids, cholesterol and apoproteins, with the production of lipoproteins, and mainly lipoproteins of very low density (VLDL) that carry triacylglycerols to various tissues and organs (Holtenius 1989). Ruminants, however, have only a limited ability to produce VLDL, which is due to their insufficient synthesis of the key component, i.e. apoprotein B (Grummer 1995). At the time of a negative energy balance, triacylglycerols thus accumulates in the liver (Grummer 1993) and liver steatosis develops.

Liver steatosis is characterized by the presence of excessive amounts of fat, mainly triacylglycerols and cholesterol esters, in liver cells. In steatosis, the content of lipids in the liver rises to $20-25 \%$ from their physiological level of around 5\%. Liver steatosis occurs most frequently in excessively fat cows after calving (lipid mobilisation syndrome) and in cows with normal body condition parameters in the early stage of lactation, when they starve and during some infectious or metabolic diseases.

One possibility of alleviating this energy deficit in dairy cows in the early lactation period is to supplement fats to their diet. The principal reason for using fats is their higher energy content in comparison with saccharides or proteins. The efficiency of the conversion of digestible energy of fats to metabolizable energy is $100 \%$ because no fermentation heat is released during the process, and losses through urine and methane are also nil.

The aim of the present investigation was to determine the influence of increased intake of fats (calciferous salts of fatty acids) in the early lactation period on the development of liver steatosis.

\section{Materials and Methods}

The experiment was conducted in eastern Bohemia in a herd of high-yield dairy cows with mean milk yield of 6,500 1. The dairy cows were kept in tie-up stalls in a barn housing. Twenty dairy cows, selected with regard to the expected delivery date, performance and age (analogous couple system), were divided into one experimental (E; $\mathrm{n}=10)$ and one control $(\mathrm{C} ; \mathrm{n}=10)$ groups. All cows were monitored for the first four weeks of lactation.

Both groups were fed the same basic diet consisting of $14 \mathrm{~kg}$ clover silage, $15 \mathrm{~kg}$ maize silage and $2 \mathrm{~kg}$ meadow hay. The production mix was calculated according to the dairy cows' milk production and delivered directly to the trough. The diets fed to the two groups were balanced with regard to the energy content, crude protein and minerals with the exception of calcium. The differences were in the fat content $3.7 \%$ and $6.99 \%$ dietary dry matter fed to the control and experimental groups, respectively), fibre (14.4\% and $15.6 \%$ dietary dry matter fed to the control and experimental group, respectively) and calcium $(0.83 \%$ and $1.3 \%$ dietary dry matter fed to the control and experimental groups, respectively). The source of fat in the diet fed to the experimental group was treated rape cake (calcium salts of fatty acids). Dietary nutrient content for dairy cows with milk production of 301 is given in Table 1. The values were computed on the basis of an individual feeds analysis.

Blood samples were collected in weeks 2 and 4 after parturition. The samples for serum were collected from $v$. jugularis into disposable test tubes and analysed for $\beta$-hydroxybutarate (BHB), nonesterified fatty acids (NEFA), total cholesterol, triacylglycerols (TAG), total bilirubin, aspartate aminotransferase (AST), $\gamma$-glutamyl transferase (GMT), lactate dehydrogenase (LDH), total protein, albumin and urea. Glucose concentration was determined from fluoride plasma. All biochemical parameters were assayed at the clinical and biological laboratory of the Clinic of Diseases of Ruminants at University of Veterinary and Pharmaceutical Sciences Brno. The values for parameters were determined by photometric methods using an automatic analyser Cobas Mira (Roche, Switzerland) and the following tests: total bilirubin (BIL 100, Cat. No. 1105309), TAG (TGL 4×100, Cat. No. 1312983), GMT (GMT KIN 100, Cat. No. 1302082), urea (Urea UV KIN $4 \times 50$ test, Cat. No. 1307017) all supplied by Lachema; glucose ( ${ }^{\mathrm{L}}$ Glukosa, Cat. No. 11601), total cholesterol ( ${ }^{\mathrm{L} C h o l e s t e r o l, ~ C a t . ~ N o .10851), ~ A S T ~(~}{ }^{\mathrm{L}}$ AST, Cat. No. 10351), LDH ( ${ }^{\mathrm{L}} \mathrm{LDH}$, Cat. No. 10351), total protein ( ${ }^{\mathrm{L} P r o t e i n}$ total, Cat. No. 12751), supplied by BioVendor; NEFA(NEFA, Cat. No. FA 115), $\beta$-HBA (Ranbut, Cat. No., RB 1008) supplied by Randox, albumin (Albumin liquicolor, Cat. No. 10560) supplied by Human. 
Table 1 . Nutrient contents in the daily ration for dairy cows with milk yield 30 litres

\begin{tabular}{|lc|c|c|}
\hline & & Experimental group & Control group \\
\hline Dry matter & $(\mathrm{g})$ & 20810.2 & 21033.8 \\
\hline Crude protein & $(\mathrm{g})$ & 3553.3 & 3587.1 \\
\hline PDIE & $(\mathrm{g})$ & 1789.8 & 1876.8 \\
\hline Fat & $(\mathrm{g})$ & 1453.9 & 777.7 \\
\hline Fibre & $(\mathrm{g})$ & 3244.9 & 3024.0 \\
\hline NEL & $(\mathrm{MJ})$ & 140.1 & 139.9 \\
\hline Calcium & $(\mathrm{g})$ & 269.0 & 174.4 \\
\hline Phosphorus & $(\mathrm{g})$ & 127.0 & 121.7 \\
\hline Sodium & $(\mathrm{g})$ & 41.3 & 41.3 \\
\hline
\end{tabular}

At week 4 postpartum, liver samples were collected for an accurate evaluation of the liver parenchyma development. Histological liver examinations were performed in the Veterinary Research Institute in Brno. Liver samples were collected by a bioptic set. The bioptic needle was introduced in the right $11^{\text {th }}$ intercostal region, approximately $2 \mathrm{~cm}$ below the horizontal line through the tuber coxae. Dairy cows were sedated by $2 \%$ Rometar, the collection site was anaesthetized by $2 \%$ Prokain and thoroughly disinfected with alcohol ether. Immediately after collection, the liver specimens were fixed in neutral $10 \%$ formaldehyde solution. For histochemical demonstrating of lipids, sections made using a freezing microtome were stained with oil red. Glycogen was demonstrated by the PAS reaction in paraffin sections (Vacek 1990). Lipid and glycogen quantification was performed by assessing the proportion of infiltrated tissue to the total area of the liver section analyzed using computer image analysis (LUCIA G Version 4.51).

Variance of values obtained in the individual sets was analysed by the F-test and subsequently by the two-sided Student's t-test with equal or unequal variance using the EXCEL software.

\section{Results and Discussion}

Levels of lipids and glycogens in liver tissue in the experimental and control groups of dairy cows are shown in Fig 1. The area of lipid-infiltrated liver tissue was larger in the control group of dairy cows $(p<0.01)$. Great steatosis, where the proportion of infiltrated tissue to the total area of the liver was $68-97 \%$, was found in $70 \%$ of experimental cows. In these cases the steatosis was characterized by large droplets and clear signs of liver dystrophy (Plate 9 , Fig. 1). On the contrary in the control group was found lower lipid infiltration in the form of minute droplets with no pathological changes of hepatocytes (Plate 9, Fig. 2).

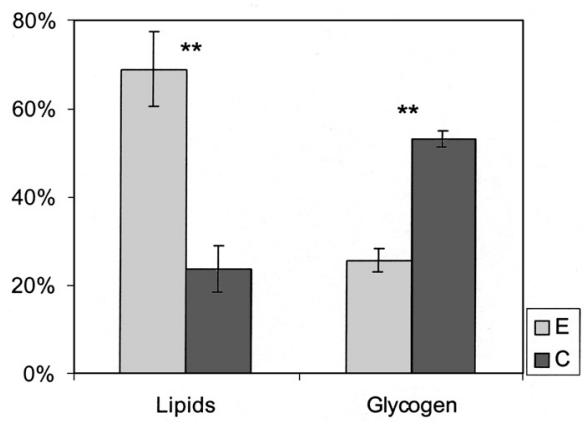

Fig. 1. Lipid and glycogen contents as a percentage of infiltrated livier tissue of dairy cows from the experimental (E) and control (C) groups in week 4 post partum. $* * p<0.01$ (between group $\mathrm{E}$ ad $\mathrm{C}$ )

Liver glycogen content in the experimental group of dairy cows was lower $(p<0.01)$ than in control group, where areas of glycogen-infiltrated liver tissue were twice as large. The evaluation of lipid and glycogen contents in the experimental group showed a statistically 
significant negative correlation coefficient $(\mathrm{r}=-0.81 ; p<0.05)$. This shows that liver steatosis developed in both groups of dairy cows. The steatosis was mild to moderately severe in the control group, and severe in the experimental group. Similar results were reported by Skaar et al. (1989). In their study, fat supplementation starting 17 days before parturition and continuing for 15 weeks after parturition resulted in increased liver TAG in the early stage of lactation. An increase in liver TAG as a result of fat supplementation during 10 day period of restricted diet was also reported by Bertics and Grummer (1999). Grum et al. (1996b) and Douglas et al. (1998) on the other hand found that fat supplementation during the entire dry period caused a decrease in liver lipid accumulations and higher glycogen concentrations after parturition. This indicates a decrease in TAG production and increase in oxidation of fatty acids in the liver after parturition. Douglas et al. (1998) nevertheless demonstrated that liver TAG levels were more affected by restricted diet in the dryoff period than by fat supplementation in combinations with an unrestricted diet. Diet restrictions also positively influenced the intake of dry matter after parturition and thus also stimulated higher milk production.

Table 2. Selected metabolic profile parameters in the experimental $(E ; n=10)$ and control $(C ; n=10)$ groups (mean \pm standard deviation)

\begin{tabular}{|c|c|c|c|}
\hline \multicolumn{2}{|l|}{ Weeks post partum } & 2 & 4 \\
\hline $\begin{array}{l}\text { Glucose } \\
{\left[\mathrm{mmol}^{-1} \mathrm{l}^{-1}\right]}\end{array}$ & $\begin{array}{l}\mathrm{E} \\
\mathrm{C}\end{array}$ & $\begin{array}{l}3.05 \pm 0.56 \\
3.09 \pm 0.78\end{array}$ & $\begin{array}{l}3.29 \pm 0.41 \\
2.81 \pm 0.88\end{array}$ \\
\hline $\begin{array}{l}\text { BHB } \\
{\left[\mathrm{mmol} \cdot \mathrm{l}^{-1}\right]}\end{array}$ & $\begin{array}{l}\mathrm{E} \\
\mathrm{C}\end{array}$ & $\begin{array}{l}1.04 \pm 0.58 * \\
0.54 \pm 0.18\end{array}$ & $\begin{array}{l}0.89 \pm 0.63 \\
0.55 \pm 0.14 \\
\end{array}$ \\
\hline $\begin{array}{l}\text { NEFA } \\
{\left[\mathrm{mmol} \cdot \mathrm{l}^{-1}\right]}\end{array}$ & $\begin{array}{l}\mathrm{E} \\
\mathrm{C}\end{array}$ & $\begin{array}{l}0.96 \pm 0.57 * \\
0.39 \pm 0.24 \\
\end{array}$ & $\begin{array}{l}0.62 \pm 0.48 * \\
0.25 \pm 0.10 \\
\end{array}$ \\
\hline $\begin{array}{l}\text { Total cholesterol } \\
{\left[\mathrm{mmol} \cdot \mathrm{l}^{-1}\right]}\end{array}$ & $\begin{array}{l}\mathrm{E} \\
\mathrm{C}\end{array}$ & $\begin{array}{l}3.54 \pm 1.29 * \\
2.51 \pm 0.44\end{array}$ & $\begin{array}{l}4.70 \pm 0.77 * * \\
3.03 \pm 0.49\end{array}$ \\
\hline $\begin{array}{l}\text { Triacylglycerol } \\
{\left[\mathrm{mmol} \cdot \mathrm{l}^{-1}\right]}\end{array}$ & $\begin{array}{l}\mathrm{E} \\
\mathrm{C}\end{array}$ & $\begin{array}{l}0.25 \pm 0.09 \\
0.27 \pm 0.08\end{array}$ & $\begin{array}{l}0.31 \pm 0.05 \\
0.32 \pm 0.05\end{array}$ \\
\hline $\begin{array}{l}\text { Total bilirubin } \\
{\left[\mu \mathrm{mol} \cdot \cdot^{-1}\right]}\end{array}$ & $\begin{array}{l}\text { E } \\
\mathrm{C}\end{array}$ & $\begin{array}{l}8.61 \pm 3.73 * \\
5.29 \pm 1.07 \\
\end{array}$ & $\begin{array}{l}6.31 \pm 2.24 \\
4.58 \pm 1.35 \\
\end{array}$ \\
\hline $\begin{array}{l}\text { Total protein } \\
{\left[\mathrm{g} \cdot \mathrm{l}^{-1}\right]}\end{array}$ & $\begin{array}{l}\mathrm{E} \\
\mathrm{C}\end{array}$ & $\begin{array}{l}78.77 \pm 5.01 * * \\
88.72 \pm 7.05\end{array}$ & $\begin{array}{l}83.80 \pm 5.74 \\
89.11 \pm 5.46\end{array}$ \\
\hline $\begin{array}{l}\text { Albumin } \\
{\left[\mathrm{g} \cdot \mathrm{l}^{-1}\right]}\end{array}$ & $\begin{array}{l}\mathrm{E} \\
\mathrm{C}\end{array}$ & $\begin{array}{l}42.10 \pm 4.14 \\
38.03 \pm 5.16 \\
\end{array}$ & $\begin{array}{l}40.63 \pm 4.30 \\
40.61 \pm 3.86 \\
\end{array}$ \\
\hline $\begin{array}{l}\text { Urea } \\
{\left[\mathrm{mmol} \cdot \mathrm{l}^{-1}\right]}\end{array}$ & $\begin{array}{l}\mathrm{E} \\
\mathrm{C}\end{array}$ & $\begin{array}{l}4.09 \pm 0.92 * \\
4.99 \pm 0.61\end{array}$ & $\begin{array}{l}4.43 \pm 1.01 \text { ** } \\
5.88 \pm 1.08\end{array}$ \\
\hline $\begin{array}{l}\text { AST } \\
{\left[\mu \mathrm{kat} \cdot \mathrm{l}^{-1}\right]}\end{array}$ & $\begin{array}{l}\mathrm{E} \\
\mathrm{C}\end{array}$ & $\begin{array}{l}2.58 \pm 1.39 \\
1.59 \pm 0.33 \\
\end{array}$ & $\begin{array}{l}1.65 \pm 0.42 \\
1.33 \pm 0.21\end{array}$ \\
\hline $\begin{array}{l}\text { GMT } \\
{\left[\mu \mathrm{kat} \cdot \mathrm{l}^{-1}\right]}\end{array}$ & $\begin{array}{l}\mathrm{E} \\
\mathrm{C}\end{array}$ & $\begin{array}{l}0.34 \pm 0.60 \\
0.31 \pm 0.08\end{array}$ & $\begin{array}{l}0.44 \pm 0.17 \\
0.35 \pm 0.09\end{array}$ \\
\hline $\begin{array}{l}\text { LDH } \\
{\left[\mu \mathrm{kat} \cdot \mathrm{l}^{-1}\right]}\end{array}$ & $\begin{array}{l}\mathrm{E} \\
\mathrm{C}\end{array}$ & $\begin{array}{l}49.79 \pm 12.43 * \\
37.20 \pm 5.48\end{array}$ & $\begin{array}{l}45.97 \pm 10.70 * \\
36.14 \pm 3.97\end{array}$ \\
\hline
\end{tabular}

$* p<0.05$ (between group $\mathrm{E}$ and $\mathrm{C}$ )

$* * p<0.01$ (between group $\mathrm{E}$ and $\mathrm{C}$ )

Results of biochemical blood tests of the experimental and the control groups are in Table 2. One of the energy metabolism parameters monitored were blood glucose concentrations. In this respect, no statistically significant differences between the two groups of dairy cows were found, and the values were within the physiological range of $3.0-3.9 \mathrm{mmol} \cdot \mathrm{l}^{-1}$ 
(Vrzgula et al. 1990). We found that increased lipid accumulation had no negative effect on blood glucose concentrations in the dairy cows. Similar conclusions were made by Madison-Anderson et al. (1997). Glycaemia adjustment is enhanced by insulin resistance, which is common in the early stage of lactation and has also been found in connection with increased liver fat depositions (Strang et al. 1998). Grummer (1999) on the other hand reported a decrease in blood glucose concentrations in dairy cows in response to fat supplementation in the first stage of lactation.

Another parameter of energy metabolism monitored was the blood serum concentration of BHB. Compared with glucose, BHB is a more sensitive indicator of energy metabolism disruptions, and its concentrations are increased by lipid mobilisation. In our study, BHB concentrations in the experimental group in week 2 post partum were elevated $(p<0.05)$ and exceeded the physiological limit of $0.6 \mathrm{mmol} \cdot \mathrm{l}^{-1}$ (Kraft and Dürr 2001) both in both week 2 and 4 post partum. Grummer (1999) also reported elevated BHB concentrations following fat supplementation during the first stage of lactation. Skaar et al. (1989) and Moallem et al. (1997) on the other hand found no effect of supplemental fat on BHB concentrations.

Energy metabolism is closely linked to lipid metabolism. In weeks 2 and 4 post partum, we found increased $(p<0.05)$ blood serum NEFA concentrations that exceeded the physiological range of $0.1-0.35 \mathrm{mmol} \cdot \mathrm{l}^{-1}$ (Vrzgula et al. 1990). Increased NEFA concentrations following the use of fat supplemented diets have also been demonstrated by Grummer and Carroll (1991), Grum et al. (1996a) and Bertrics and Grummer (1999). Salfer et al. (1995) and Skaar et al. (1989), on the other hand, found no effect of fat supplementation on NEFA concentrations, while Grum et al. (1996b) reported a decrease in NEFA concentrations when fat supplemented diet was fed during the entire dry period. Kronfeld (1982) hypothesized that supplemental fat might reduce the mobilisation of fatty acids from the adipose tissue. The dietary fat in the intestines is involved in the synthesis of lipoproteins, which are preferentially metabolised by tissues other than the liver, while fatty acids mobilized from the adipose tissue are utilized mainly by the liver. An increase in the blood serum NEFA concentrations is characteristic for the onset of the lipid mobilisation syndrome in dairy cows, and it is the triggering factor for liver steatosis. NEFA concentrations reach their highest level in the period around parturition (S alfer et al. 1995; Skaar et al. 1989) due to lower feed intake and high energy consumption in the early lactation period. NEFA concentrations gradually decrease and, if the feed intake increases and the production of milk decreases, they level off at around day 66 after parturition (Salfer et al. 1995).

Parameters of lipid metabolism were also investigated. Liver steatosis decreases total cholesterol and TAG concentrations (Pechová et al. 1997; Sevinc et al. 2003). In the present study, higher concentrations of total cholesterol in blood serum were found in the experimental group of dairy cows in both week 2 and 4 post partum $(p<0.05$ and $p<0.01$, respectively). Their values were within their physiological range of $2.6-5.2 \mathrm{mmol} \cdot \mathrm{l}^{-1}$ (Vrzgula et al. 1990). Espinoza et al. (1995) also reported elevated cholesterol concentrations following fat supplementation during the first stage of lactation. TAG concentrations showed no significant differences, and their values were within their physiological range of $0.17-0.51 \mathrm{mmol}^{-1} \mathrm{l}^{-1}$ (Kraft and Dürr 2001). Espinoza et al. (1995), on the other hand, reported elevated TAG when fat supplemented diets were fed during the first stage of lactation. Our results indicate that supplemental fat causes an increase in total cholesterol concentrations but has no effect on TAG blood concentrations in dairy cows, in spite of lipid accumulation in the liver and the development of liver steatosis.

The total bilirubin value is a sensitive indicator of liver damage. A significant correlation 
between the amount of lipids in the liver and total bilirubin concentrations has been reported by Reichel et al. (1999). In the present study, higher concentrations of total bilirubin in the blood serum $(p<0.05)$ were found in the experimental group in week 2 post partum. In weeks 2 and 4 post partum, the values found in the experimental group exceeded the physiological range of $0.17-5.13 \mu \mathrm{mol} \cdot 1^{-1}$ (Vrzgula et al. 1990).

The nitrogen metabolism parameters monitored included total protein, albumin and urea concentrations whose decreased blood levels are symptomatic of serious liver damage. In the present study, lower concentrations of total blood serum protein $(p<0.01)$ were found in the experimental group in week 2 post partum. The post partum decrease in total blood protein in dairy cows may be caused by the transfer of albumin and $\gamma$-globulins from blood to the mammary gland (Kupczyński et al. 2002). In the experimental group, lower urea concentrations were found in weeks 2 and 4 post partum $(p<0.05$ and $p<0.01$, respectively). These differences may have been caused by the lower utilization of ammonia in the rumen. Strang et al. (1998) found decreased ureagenesis with accumulation of TAG in bovine hepatocytes. Blood plasma albumin concentrations in dairy cows showed no significant differences, and were within the physiological range of $30-42 \mathrm{~g} \cdot \mathrm{l}^{-1}$ (Vrzgula et al. 1990). Albumin is the indicator of the synthetic capability of the liver. A decrease in its blood concentrations occurs mainly in chronic liver diseases when the functional liver area is reduced to $20 \%$ or less. It is encountered mainly in medium or severe liver steatosis and in liver failure (Sevinc et al. 2003). Our results showed that supplemental fat and the ensuing lipid accumulation in the liver did to a certain extent affect the synthetic functions of the liver but they did not cause any major disruption of the nitrogenous metabolism.

Another important parameter that provides complementary evidence of liver damage is enzyme activity. The enzymes monitored in the present study were AST, GMT and LDH. AST occurs in the cytoplasm and mitochondria of various tissues and organs, and high levels of its activity are detected in the cardiac and skeletal muscles and in the liver. In the present study, higher blood serum AST activity was found in the experimental group of dairy cows in weeks 2 and 4 post partum, but the difference was not significant. In week 2 post partum, AST activity in both groups of dairy cows exceeded the physiological range of $0.17-1.41$ $\mu \mathrm{kat} \cdot \mathrm{l}^{-1}$ (Pechová 1992). In week 4 , the range was exceeded in the experimental group only. AST is considered the most sensitive enzyme for the diagnosis of liver steatosis in the cattle, and its activity increases with the increase in the liver fat content (Pechová et al. 2002). Ku pczyński et al. (2002) reported elevated AST activity in dairy cows post partum at the time of higher metabolic demands and as a result of pathological changes in the post partum period, e.g. reproduction disorders, damage to parenchymatous organs and energy metabolism disorders.

In both groups of dairy cows, blood serum gamaglutamyltransferase (GMT) activity was within the physiological range of $0.14-0.55 \mu \mathrm{kat} \cdot \mathrm{l}^{-1}$ (Pechová 1992). In the experimental group, the values were insignificantly higher than in the control group. GMT is a microsomal and membrane-bound enzyme, and it is found mainly in the liver, the kidneys and the small intestine. Its activity increases as a result of damage to the cellular structures of hepatocytes (Kupczyński et al. 2002) and the disease of the biliary ducts (Kraft and Dürr 2001).

The last of the enzymes studied was lactate dehydrogenase (LDH). LDH is not organ-specific, and it is found in high concentrations in muscles, the heart, the kidney and the liver. It is released to the blood on an acute damage to cells of those organs. Blood serum LDH activity was increased $(p<0.05)$ in week 2 post partum. The physiological range of $16.3-29.0 \mu \mathrm{kat} \cdot \mathrm{l}^{-1}$ (P ec hová 1992) was exceeded in both groups of the dairy cows. The increase in LDH activity was related to an increase in the degree of liver steatosis (Pechová et al. 1997). Asmare et al. (1999), on the other hand, found no significant changes in serum LDH activity linked to liver damage, although they were able to demonstrate a degree of influence in a study of LDH isoenzymes. 
Our investigations suggest that fat supplemented at the level of $6.98 \%$ of dietary dry matter increases the risk of liver steatosis in the post partum period.

\section{Vliv suplementace tuku v krmné dávce dojnic na rozvoj steatózy jater}

Cílem práce bylo ověřit, zda zvýšený př́ijem tuku (vápenaté soli mastných kyselin) v první fázi laktace ovlivní rozvoj steatózy jater. Sledováno bylo 20 dojnic, rozdělených na skupinu pokusnou $(\mathrm{E} ; \mathrm{n}=10)$ a kontrolní $(\mathrm{C} ; \mathrm{n}=10)$. Krmná dávka obou skupin měla vyrovnaný obsah energie, dusíkatých látek a minerálních látek, kromě vápníku. Rozdíl byl v obsahu tuku (kontrolní skupina 3.7 \% sušiny krmné dávky vs. pokusná skupina $6.99 \%$ sušiny krmné dávky), vlákniny (kontrolní skupina $14.4 \%$ sušiny krmné dávky vs. pokusná skupina 15.6 \% sušiny krmné dávky) a vápníku (kontrolní skupina 0.83 \% sušiny krmné dávky vs. pokusná skupina $1.3 \%$ sušiny krmné dávky. Zdrojem tuku v krmné dávce pokusné skupiny byly upravené řepkové výlisky (vápenaté soli mastných kyselin). Podávání obou krmných dávek začalo dnem otelení. Vzorky krve byly odebírány 2. a 4. týden po porodu, biopsie jater byla provedena ve 4 . týdnu po porodu.

Histologické vyšetření jaterních vzorků ukázalo signifikantně vyšší lipidovou infiltraci $(69.03 \pm 8.42$ vs. $23.83 \pm 5.16 \% ; p<0.01)$ a signifikantně nižší koncentraci jaterního glykogenu $(25.74 \pm 2.74 \%$ vs. $53.15 \pm 1.74 \% ; p<0.01)$. Pokusná skupina měla v krevním séru ve 2. týdnu po porodu signifikantně vyšší koncentraci betahydroxybutyrátu - BHB $\left(1.04 \pm 0.58\right.$ vs. $\left.0.54 \pm 0.18 \mathrm{mmol} \cdot 1^{-1} ; p<0.05\right)$, neesterifikovaných mastných kyselin - NEFA $\left(0.96 \pm 0.57\right.$ vs. $\left.0.39 \pm 0.24 \mathrm{mmol} \cdot \mathrm{l}^{-1} ; p<0.05\right)$, celkového cholesterolu (3.54 \pm 1.29 vs. $\left.2.51 \pm 0.44 \mathrm{mmol} \cdot \mathrm{l}^{-1} ; \mathrm{p}<0.05\right)$, celkového bilirubinu $\left(8.61 \pm 3.73 \mathrm{vs} .5 .29 \pm 1.07 \mu \mathrm{mol} \cdot \mathrm{l}^{-1}\right.$; $p<0.05)$, laktátdehydrogenázy - LDH (49.79 \pm 12.43 vs. $\left.37.20 \pm 5.48 \mu \mathrm{kat}^{-1} \mathrm{l}^{-1} ; p<0.05\right)$, dále signifikantně nižší koncentraci celkové bílkoviny $\left(78.77 \pm 5.01\right.$ vs. $88.72 \pm 7.05 \mathrm{~g} \cdot \mathrm{l}^{-1}$; $\mathrm{p}<0.01)$ a močoviny $\left(4.09 \pm 0.92\right.$ vs. $\left.4.99 \pm 0.61 \mathrm{mmol} \cdot \mathrm{l}^{-1} ; \mathrm{p}<0.05\right)$. Ve 4 . týdnu po porodu měla pokusná skupina signifikantně vyšší koncentraci NEFA $(0.62 \pm 0.48$ vs. $0.25 \pm$ $\left.0.1 \mathrm{mmol} \cdot \mathrm{l}^{-1} ; p<0.05\right)$, celkového cholesterolu $\left(4.70 \pm 0.77\right.$ vs. $3.03 \pm 0.49 \mathrm{mmol} \cdot \mathrm{l}^{-1}$; $p<0.01)$, LDH $\left(45.97 \pm 10.70\right.$ vs. $\left.36.14 \pm 3.97 \mu \mathrm{kat} \cdot \mathrm{l}^{-1} ; p<0.05\right)$ a signifikantně nižš́ koncentraci močoviny ( $4.43 \pm 1.01$ vs. $\left.5.88 \pm 1.08 \mathrm{mmol}^{-1} \mathrm{l}^{-1} ; p<0.01\right)$.

Na základě našeho sledování má zvýšený př́ijem tuku (6.99 \% sušiny krmné dávky) v první fázi laktace podstatný vliv na rozvoj steatózy jater.

\section{Acknowledgement}

This study was supported by the Grant Agency of the Ministry of Education (Grant No. 161700002) and grant project of the Ministry of Agriculture (MZE 0002716201).

\section{References}

ASMARE, AA, KOVÁČ, G, REICHEL, P, ŠČUROKOVÁ, E 1999: Serum LDH isoenzymes activity and other constituents to predict liver damage in dairy cows. Czech J Anim Sci 44: 5-12

BERTICS, SJ, GRUMMER, RR 1999: Effects of fat and methionine hydroxy analog on prevention or alleviation of fatty liver induced by feed restriction. J Dairy Sci 82: 2731-2736

DOUGLAS, GN, DRACKLEY, JK, OVERTON, TR, BATEMAN, HG 1998: Lipid metabolism and production by holstein cows fed control or high fat diets at restricted or ad libitum intakes during the dry period. J Dairy Sci 81(Suppl. 1): 295

ESPINOZA, JL, RAMIREZGODINEZ, JA, JIMENEZ, JA, FLORES, A 1995: Effects of calcium soaps of fattyacids on postpartum reproductive activity in beef-cows and growth of calves. J Anim Sci 73: 2888-2892

GRUM, DE, DRACKLEY, JK, HANSEN, LR, CREMIN, JD 1996a: Production, digestion, and hepatic lipid metabolism of dairy cows fed increased energy from fat or concentrate. J Dairy Sci 79: 1836-1849

GRUM, DE, DRACKLEY, JK, YOUNKER, RS, LaCOUNT, DW, VEENHUIZEN, JJ 1996b: Nutrition during the dry period and hepatic lipid metabolism of periparturient dairy cows. J Dairy Sci 79: 1850-1864

GRUMMER, RR 1993: Etiology of lipid-related metabolic disorders in periparturient dairy cows. J Dairy Sci 76: 3882-3896

GRUMMER, RR 1995: Impact of changes in organic nutrient metabolism on developing feeding strategies to minimize stress during the transition from late pregnancy to early lactation. J Anim Sci 73: 2820-2833 
GRUMMER, RR 1999: Energy and protein nutrition on the transition dairy cow. Dairy Nutritional Conference. Department of Dairy Science University of Wisconsin [cit. 2002-04-11]. Available on-line [www.wisc.edu/dysci/uwex/nutritn/pubs/NutrAndMgt/energya0.pdf]

GRUMMER, RR, CARROLL, DJ 1991: Effects of dietary fat on metabolic disorders and reproductive performance of dairy cattle. J Anim Sci 69: 3838-3852

HOLTENIUS, P 1989: Plasma lipids in normal cows around partus and in cows with metabolic disorders with and without fatty liver. Acta Vet Scand 30: 441-445

KRAFT, W, DÜRR, UM 2001: Klinická laboratórna diagnostika vo veterinárnej medicíne. Bratislava, Hajko \& Hajková, 365 p.

KRONFELD, DS 1982: Major metabolic determinants of milk volume, mammary efficiency, and spontaneous ketosis in dairy cows. J Dairy Sci 65: 2204-2212

KUPCZYŃSKI, R, CHUDOBA-DROZDOWSKA, B 2002: Values of selected biochemical parameters of cows' blood during their drying-off and the beginning of lactation. Electronic Journal of Polish Agricultural Universities [cit. 2003-05-28]. Available on-line [http://www.ejpau.media.pl/series/volume5/issue1/veterinary/ /art-01.html]

MADISON-ANDERSON, RJ, SCHINGOETHE, DJ, BROUK, MJ, BAER, RJ, LENTSCH, MR 1997: Response of lactating cows to supplemental unsaturated fat and niacin. J Dairy Sci 80: 1329-1338

MOALLEM, U, KAIM, M, FOLMAN, Y, SKLANT, D 1997: Effect of calcium soaps of fatty acids and administration of somatotropin in early lactation on productive and reproductive performance of high producing dairy cows. J Dairy Sci 80: 2127-2136

PECHOVÁ, A 1992: Diagnostika a prevence lipomobilizaãního syndromu u dojnic v poporodním období. Kandidátská disertace. Veterinární a farmaceutická univerzita Brno, 170 p.

PECHOVÁ, A, LLEK, J, HALOUZKA, R 1997: Diagnosis and control of the development of hepatic steatosis in dairy cows in the periparturient period. Acta Vet Brno, 66: 235-243

PECHOVÁ, A, ILLEK, J, PAVLATA, L 2002: Einwirkungen der Lebersteatose auf den Stoffwechsel bei Milchkıhen. Wien Tierarztl Monatschr 89: 325-332

RUKKWAMSUK, T, WESING, T, GEELEN, MJH 1999: Effect of fatty liver on hepatic gluconeogenesis in periparturient dairy cows. J Dairy Sci 82: 500-505

SALFER, JA, LINN, JG, OTTERBY, DE, HANSEN, WP 1995: Early lactation responses of holstein cows fed a rumen-inert fat prepartum, postpartum, or both. J Dairy Sci 78: 368-377

SEVINC, M, BASOGLU, A, GUZELBEKTAS, H 2003: Lipid and lipoprotein levels in dairy cows with fatty liver. Turk J Vet Anim Sci 27: 295-299

SKAAR, TC, GRUMMER, RR, DENTINE, MR, STAUFFACHER, RH 1989: Seasonal effects of pre- and postpartum fat and niacin feeding on lactation performance and lipid metabolism. J Dairy Sci 72: 2028-2038

STRANG, BH, BERTRICS, SJ, GRUMMER, RR, ARMENTANO, LE 1998: Effect of long-chain fatty acids on triglyceride accumulation, gluconeogenesis, and ureagenesis in bovine hepatocytes. J Dairy Sci 81: 728-739

VACEK, Z 1990: Histológia a histologická technika. Osveta, 503 p.

VAN DEN TOP, AM, WENSING, T, GEELEN, MJH, WENTINK, GH, VAN'T KLOOSTER, AT, BEYNEN, AC 1995: Time trends of plasma lipids and enzymes synthetizing hepatic triacylglycerol during postpartum development of fatty liver in dairy cows. J Dairy Sci 78: 2208-2220

VRZGULA, L et al. 1990: Poruchy látkového metabolizmu hospodárskych zvierat a ich prevencia. 2.vyd., Bratislava, Príroda, 503 p. 
Plate IX

Lubojacká V. et al.: Liver steatosis.... pp. 217-224

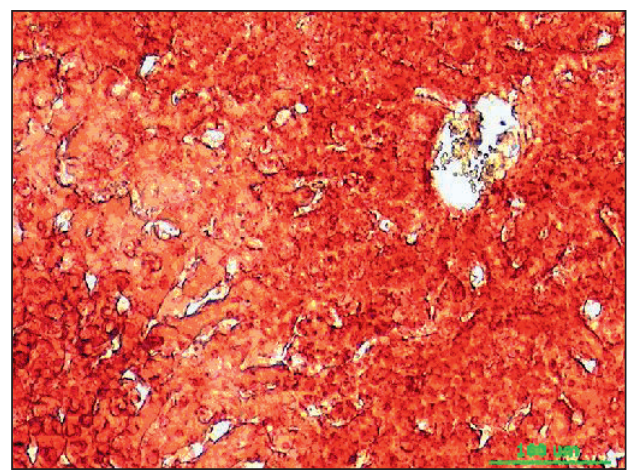

Fig. 1. Bioptic sample of the liver of dairy cows from the experimental group stained with oil red for the detection of neutral fats

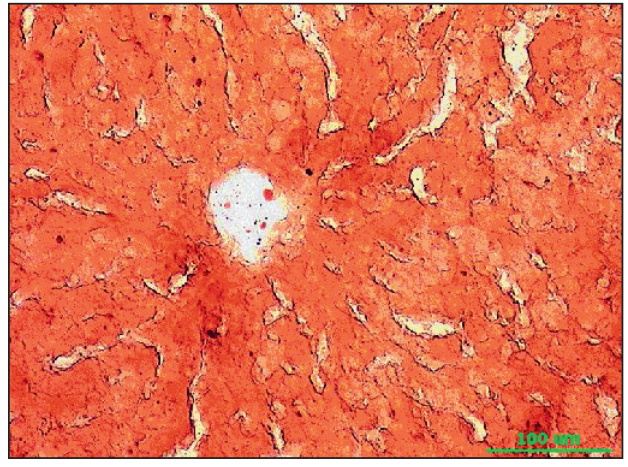

Fig. 2. Bioptic sample of the liver of dairy cows from the controll group stained with oil red for the detection of neutral fats 